\title{
MANUSCRIPT
}

for publication in the

International Journal of Hydrogen Energy

\section{Open and closed metal hydride system for high thermal power applications: preheating vehicle components}

\author{
Mila Dieterich", Inga Bürger and Marc Linder
}

German Aerospace Center (DLR) - Institute of Engineering Thermodynamics, Thermal Process Technology, Pfaffenwaldring 38-40, 70569 Stuttgart, Germany

*Corresponding author: phone: +49 711-6862 214; fax: +49 711-6862 632

e-mail: mila.dieterich@dlr.de

\begin{abstract}
Many vehicle components operate at temperatures above ambient conditions. At cold start, most of the pollutants are produced and lifespan is reduced. Thermochemical energy storage with high power density could prevent these disadvantages. In order to investigate achievable power densities of a thermochemical energy storage at technically relevant boundary conditions, a laboratory scale device using metal hydrides $\left(\mathrm{LaNi}_{4.85} \mathrm{Al}_{0.15}\right.$ and $\left.\mathrm{C}^{\circledR}\right)$ is designed and preheating operation modes (open and closed) are analyzed. The impact of the ambient temperature (from -20 to $+20^{\circ} \mathrm{C}$ ), a s well as other influencing factors on the thermal power output such as heat transfer flow rate, regeneration temperature and pressure conditions are investigated. The experiments proved the suitability of the reactor design and material selection for the considered application boundary conditions. For the coupled reaction (closed system), the ambient temperature has the greatest influence on the thermal power with decreasing values for lower temperatures. Here, values between $0.6 \mathrm{~kW} / \mathrm{kg}_{\mathrm{MH}}$ at ambient temperature of $-20^{\circ} \mathrm{C}$ and $1.6 \mathrm{~kW} / \mathrm{kg}_{\mathrm{MH}}$ at $20^{\circ} \mathrm{C}$, at otherwise same conditions, were reached. If hydrogen can be supplied from a pressure tank (open system), the supply pressure in relation to equilibrium pressure at the considered ambient temperature has to be large enough for high thermal power. At $-20^{\circ} \mathrm{C}, 1.4 \mathrm{~kW} / \mathrm{kg}_{\mathrm{MH}}$ at a supply pressure of 1.5 bar and $5.4 \mathrm{~kW} / \mathrm{kg}_{\mathrm{MH}}$ at a hydrogen pressure of 10 bar were reached.
\end{abstract}




\section{Keywords}

Thermochemical energy storage; metal hydrides; high power; cold start; coupled chemical reaction

\section{Nomenclature}

$\begin{array}{ll}c_{p} & \text { heat capacity } \\ \dot{m} & \text { mass flow } \\ P & \text { thermal power } \\ p & \text { pressure } \\ Q & \text { overall heat } \\ R & \text { universal gas constant } \\ T & \text { temperature } \\ x & \text { hydrogen conversion } \\ \Delta H & \text { reaction enthalpy } \\ \Delta S & \text { reaction entropy }\end{array}$

Subscripts:

$\begin{array}{ll}300 \mathrm{sec} & \text { after } 300 \text { seconds } \\ 600 \mathrm{sec} & \text { after } 600 \text { seconds } \\ \text { amb } & \text { at ambient level } \\ e q & \text { equilibrium state } \\ \mathrm{fc} & \text { fuel cell } \\ \mathrm{H}_{2} & \text { hydrogen } \\ \text { heat } & \text { produced heat level } \\ \mathrm{HTF} & \text { heat transfer fluid } \\ \text { in } & \text { at inlet of reactor } \\ \text { MH } & \text { metal hydride } \\ \text { out } & \text { at outlet of reactor } \\ \text { reg } & \text { regeneration level } \\ \text { storage } & \text { hydrogen storage material } \\ \text { tank } & \text { at tank level } \\ \text { waste } & \text { waste heat source }\end{array}$

\section{Introduction}

Many vehicle components operate at temperatures above ambient conditions. At cold start, especially at winter temperatures of $-20^{\circ} \mathrm{C}$ and below, most of the pollutants are produced and lifespan is reduced. This is described here in more detail for combustion drives and fuel cells.

Conventional engines are designed for temperatures around $100^{\circ} \mathrm{C}$. Starting at ambient temperatures neither the combustion process nor the exhaust gas treatment work sufficiently until operation temperature is reached. In these first couple of minutes, $60-80 \%$ of all pollutants of the whole driving cycle are produced $[1,2]$. As combustion engines become more and more efficient, waste heat is reduced and this leads to a prolonged cold start phase and more pollutants. If the components are preheated, a large amount of the pollutants can be prevented. 
Even in fuel cell driven vehicles, water produced in fuel cells would freeze below zero degrees. The ice layer prevents gas flow and the expansion in volume can cause mechanical destruction of the fuel cell [3-6]. Therefore, fuel cells are dried before shut down. When restarting, the membrane has to be wetted which requires temperatures above freezing point. So the fuel cell needs to be preheated to temperatures above $0^{\circ} \mathrm{C}$ in order to avoid degradation and prolonging life time significantly.

Therefore, both combustion engines as well as fuel cells require preheating for long service life and reduced exhaust emissions. Since in both cases thermal energy is available later during the driving cycle, thermal energy storages are a suitable option to overcome the described problem. A high energy density of the application, including both storage material and containment, is of importance, because the thermal storage adds weight to the vehicle. A promising option is a thermochemical energy storage system, due to the high energy density at limited temperature conditions and its long-term storage possibility. Here, a gas reacts with a solid and absorption heat is released. If heat is supplied to the storage material, the gas is released while heat is absorbed. This relation between solid temperature and gas pressure is described in the Van't Hoff equation [7]:

$$
\ln \left(p_{e q}\right)=-\frac{\Delta H}{R T}+\frac{\Delta S}{R}
$$

Where $p_{e q}$ is the equilibrium pressure of the gas, $\Delta H$ is the reaction enthalpy, $R$ is the universal gas constant, $T$ is the absolute temperature of the solid and $\Delta S$ is the reaction entropy. By controlling the chemical reaction, generating heat on demand and controlling the temperature and power of the released thermal energy is possible.

This study focuses on the investigation of metal hydrides for high power thermal energy storage systems. In this case, a metal alloy forms a hydride phase by chemisorption of hydrogen. Originally metal hydrides were investigated as hydrogen storage materials [8-10]. But because they release and absorb heat during reaction, more and more investigations deal with thermal applications such as e.g. thermally driven heat pumps [11-20]. Consequently, the available data in literature deals mainly with temperatures above freezing point. However, the intended application in this paperthe pre-heating of components - addresses also automotive applications with respective temperature conditions for both metal hydrides down to $-20^{\circ} \mathrm{C}$. Since according to Arrhenius the reaction rate decreases at lower temperatures, the most important but so far hardly investigated aspect is related to the technically achievable power densities of metal hydrides at these boundary conditions. The systems developed in this work are designed for the following two generic applications:

a) Combustion engines - coupled reaction as a closed system. At nominal operation the combustion engine releases around $2 / 3$ of the energy as heat [21] and consequently cooling is needed. This thermal energy can be stored in a thermochemical energy storage consisting of two reactors with different metal hydrides. The thermal energy leads to a desorption of hydrogen in one of the reactors. The released hydrogen is stored in the second reactor. This closed system doesn't require any exchange of hydrogen with the surrounding, but works only by absorbing and releasing heat. If the back reaction is prevented, e.g. by a separating valve, the chemically stored thermal energy can be released at the next cold start by opening the valve to preheat the respective component. 
b) Fuel cells - hydrogen supply from tank as an open system. The potential energy stored in the hydrogen pressure tank, e.g. around $15 \%$ of the overall energy stored at 900 bar [22], is currently throttled on board and therefore lost. By conducting hydrogen at higher pressure onto a metal hydride, heat can be produced, e.g. to preheat the fuel cell. For regeneration, the waste heat of the fuel cell can be used to regenerate the thermochemical storage. In this open system, a combination of thermal energy from the fuel cell and the potential energy of the hydrogen tank is used to run the system. The hydrogen itself is not consumed since it is desorbed during regeneration and can be converted to electricity in the fuel cell.

Both applications (open and closed system) have in common that the chemical potential of the thermochemical energy storage is used to generate thermal energy when it is needed. Depending on the type of propulsion, the regeneration of the storages differs. However, the underlying challenge can be summarized to the requirement of high thermal power densities at technically relevant boundary conditions. Even though it is generally assumed that the chemisorption of metal hydrides possess very fast reaction rates $[23,24]$ until now, little data exists of metal hydride characteristics at very low temperatures. Moreover, experimental data of coupled reactions at relevant scale and at temperatures below freezing point is not available in literature. Therefore, this aspect is explicitly addressed and investigated in this work. For this purpose, a test bench is designed to investigate the influencing factors on high thermal power at vehicle temperature boundary conditions down to $-20^{\circ} \mathrm{C}$ for two different operation principles (combustion engines and fuel cells). Appropriate materials are selected and reactors are designed. In order to investigate the various influencing aspects, the mass flow of the heat transfer fluid (HTF), the ambient temperature, the regeneration conditions for the closed system as well as the supply pressure for the open system are varied. The experimental results are presented and discussed in the following.

\section{Methodology and experimental details}

The investigated systems are designed to produce heat at very low temperatures. Therefore, temperatures ranging from $-20^{\circ} \mathrm{C}$ to $+20^{\circ} \mathrm{C}$ were set as ambient conditions. Both systems are able to operate even at lower ambient temperatures, although this might affect the achievable temperature level of preheating. In the following section the two operation designs of the closed and open system are described as well as their possible application in vehicles including temperature and pressure boundary conditions for the material selection. Then, the test bench, the reactor design and the measured and calculated values are described. At the end, the experimental design and varied parameters are discussed.

\subsection{Operation design}

In the closed system hydrogen has to be stored in a second reactor containing a metal hydride with different thermodynamics. At the same (ambient) temperature, different equilibrium pressures result in the reactors separated by a valve. When the valve is opened, hydrogen flows from the "storage reactor" to the "heat generating reactor". It is absorbed here, producing heat and maintaining the pressure difference between the reactors. Hence, the other metal hydride desorbs hydrogen. This process continues until the storing reactor cannot desorb or the heat reactor cannot absorb hydrogen anymore. To regenerate, waste heat is provided to the heat reactor causing the 
pressure to rise, while the storage reactor is maintained at ambient temperature. This causes a pressure difference in the other direction and hydrogen flows back into the storage reactor. Once all hydrogen is exchanged, the valve is closed and the heat reactor is allowed to cool to ambient temperature. No insulation is needed. When thermal energy is needed, the valve is opened and heat is produced from ambient temperature independent of the storage time without losses of the thermochemical energy.

The system design for this closed system is inspired by general vehicle applications to investigate the potential under relevant boundary conditions. However, it doesn't claim to be a mature component considering all aspects for vehicle integration. Waste heat in combustion engines occurs for example in the cooling circuit or the engine lubricant. At cold start, increasing the temperature of the cooling circuit increases the temperature of the engine, too. This leads to less wall quenching in the cylinder and higher combustion temperatures which decreases the amount of pollutants like unburned hydrocarbons and carbon oxide $[25,26]$. This also leads to faster heating and functionality of the catalytic converter. Preheating of the engine lubricant has a similar effect. In addition, its viscosity decreases exponentially with temperature [27]. Every single Kelvin of increased temperature leads to less mechanical stress on the oil, leading to better lubrication properties and longer lifetime of the oil and the engine.

The assumed vehicle temperature boundary conditions for closed system in this work are as follows:

- $T_{a m b}=-20 \ldots 20^{\circ} \mathrm{C}$

- $T_{\text {waste }}=T_{\text {reg }}=90 \ldots 130^{\circ} \mathrm{C}$

- $T_{\text {heat }}:$ subject of investigation

The equilibrium pressure boundary conditions for the reaction material are the following:

- $p_{\text {storage }}>p_{\text {heat }}$ at the same temperature

- $p_{\text {heat }}\left(T_{\text {reg }}\right)>p_{\text {storage }}\left(T_{\text {amb }}\right)$

where $p_{\text {storage }}$ refers to the "storage reactor" and $p_{\text {heat }}$ to the "heat producing reactor".

In contrast to the closed system, the open system works with hydrogen from the infrastructure of the car. Heat is produced when hydrogen is conducted from the tank onto the metal hydride. To desorb the hydrogen and hence store thermal energy, the waste heat of the fuel cell is used. The released hydrogen is consumed by the fuel cell.

In order to be able to directly use the infrastructure of a fuel cell vehicle and to provide heat even at low tank level, the supply pressure was assumed to be at 10 bar and below. A polymer electrolyte fuel cell (PEFC, old: proton exchange membrane (PEM) fuel cell) works at hydrogen pressures of around 1-3 bar and temperatures between 60 and $80^{\circ} \mathrm{C}$ [28] which can be used as regeneration heat for the thermal energy storage. Experimental constrains limited the release of hydrogen at pressures above 1 bar. However, this does not affect the general investigation, but needs to be taken into account for a later integration.

Consequently, the vehicle boundary conditions for the open system in this work are the following:

- $T_{a m b}=-20 \ldots 20^{\circ} \mathrm{C}$

- $T_{\text {waste }}=T_{\text {reg }}=60-80^{\circ} \mathrm{C}$ 
- $T_{\text {heat }} \geq 20 \mathrm{~K}$ (to reach at least $0^{\circ} \mathrm{C}$ )

- $p_{\text {tank }}=1.5$...10 bar

- $p_{f c}=1 \mathrm{bar}$

The equilibrium pressure boundary conditions for the reaction material are:

- $p_{\text {heat }}\left(T_{\text {reg }}\right)>p_{f c}$

- $p_{\text {heat }}=3 \ldots 20 \mathrm{bar}$

- $T_{\text {heat }}\left(p_{\text {heat }}\right) \geq 0^{\circ} \mathrm{C}$

\subsection{Material selection}

For the material selection, the described boundary conditions are indicated in a Van't Hoff plot in Error! Reference source not found.. The suited materials are $\mathrm{LaNi}_{4.85} \mathrm{Al}_{0.15}$ from WholeWin (China) for the heat producing side and Hydralloy $\mathrm{C5}^{\circledR}\left(\mathrm{Ti}_{0.95} \mathrm{Zr}_{0.05} \mathrm{Mn}_{1.56} \mathrm{~V}_{0.46} \mathrm{Fe}_{0.09}\right)$ from GfE Metalle und Materialien $\mathrm{GmbH}$ (Germany) for the hydrogen storage side in the closed system. Their thermodynamics are included in Error! Reference source not found.. This theoretical consideration does not take pressure losses etc. into account. The blue areas indicate the conditions for heat production (closed: ambient temperature, open: supply pressure from tank), the red areas the regeneration temperature and the orange areas show the temperature range of the produced heat. In the closed system (Error! Reference source not found., left), the ambient temperature determines the hydrogen pressure for heat production. If $\mathrm{C} 5$ desorbs hydrogen at $-20^{\circ} \mathrm{C}$ the resulting pressure leads to heat production of around $25^{\circ} \mathrm{C}$ if absorbed onto $\mathrm{LaNi}_{4.85} \mathrm{Al}_{0.15}$ (indicated by the lower solid orange arrow). The desorption pressure of $\mathrm{C} 5$ at $20^{\circ} \mathrm{C}$ leads to an absorption temperature of $75^{\circ} \mathrm{C}$ of $\mathrm{LaNi}_{4.85} \mathrm{Al}_{0.15}$ (upper solid orange arrow). Hence, heat can be produced theoretically between 25 and $75^{\circ} \mathrm{C}$. At regeneration temperature of $130^{\circ} \mathrm{C}$, the pressure of desorbed hydrogen from $\operatorname{LaNi} i_{4.85} \mathrm{Al}_{0.15}$ results in an absorption heat at $50^{\circ} \mathrm{C}$ in the "storage reactor" $\left(\mathrm{C5}^{\circledR}\right)$ which can be dissipated to ambient (upper dotted orange arrow). At temperatures of $90^{\circ} \mathrm{C}$ the absorption heat of $\mathrm{C} 5$ can only be dissipated at ambient temperatures below $10^{\circ} \mathrm{C}$ (lower dotted orange arrow). Complete regeneration might therefore not be possible in all cases for the closed system which is investigated in 3.2 .

The material in the open system (Error! Reference source not found., right) can produce heat at a temperature level between 40 and $90^{\circ} \mathrm{C}$ at the given supply pressure range. Since the hydrogen gas is taken from the hydrogen tank, this is independent of the ambient temperature. For desorbing hydrogen at pressures above $1 \mathrm{bar}$, regeneration temperatures of above $30^{\circ} \mathrm{C}$ are necessary. The selected materials have fast kinetics and in theory fit the boundary conditions quite well. The actual suitability is shown in the following results.

\subsection{Test bench and experimental procedure}

Micro tube bundle heat exchangers were chosen as reactors since they allow for high power applications due to the large surface area per volume. A drawing is given in Error! Reference source not found.. Metal hydride powder is located on the shell side, the heat transfer fluid (HTF) flows through the tubes. As the system works at pressures close to ambient or below, a gap at the top of the horizontal reactors is ensured to simplify the distribution of the hydrogen gas (clipped baffle plates). Commercially available heat exchangers by Exergy Heat Transfer Solutions (Model \# 0025606 with clipped baffles) are used to realize high thermal power. They consist of 91 tubes with an 
outer diameter of $2.4 \mathrm{~mm}$ and $508 \mathrm{~mm}$ of length, a total diameter of $41 \mathrm{~mm}$ and a maximal distance to the tubes of $1.15 \mathrm{~mm}$. The reactors were filled with the corresponding amount of material so both can store about the same amount of hydrogen. The "heat generating reactor" (reactor 1 ) contains $960 \mathrm{~g}$ of $\mathrm{LaNi}_{4.85} \mathrm{Al}_{0.15}(\mathrm{x} \approx 1.0 \mathrm{wt}$. -\%) and the "storage reactor" (reactor 2 ) contains $615 \mathrm{~g}$ Hydralloy $\mathrm{C} 5^{\circledR}(\mathrm{x} \approx 1.5$ wt. $-\%)$.

A test bench is designed to investigate the system. It is able to mimic the required temperatures with the help of a heat transfer fluid, supply hydrogen and measure and log the required data. Error!

Reference source not found. shows a picture of the two reactors integrated into the test bench (left) and a schematic drawing including thermostatic baths, measurement positions of the acquired data and valves (right). Both reactors are shown as in the closed system. For the open system, only reactor 1 was operated.

The temperatures of the HTF are measured by resistance thermometer (Pt100 according to DIN EN 60751), the mass flows are measured by Coriolis mass flow meters (measurement range set to $0 \ldots 1000 \mathrm{~kg} / \mathrm{h}$, measurement uncertainty of $\pm 0.10 / 0.15 \% \mathrm{RD}$ for reactor $1 / 2$, respectively) and the pressure is measured by a piezoresistive pressure sensor (measurement range of $0 . .40$ bar $_{\text {abs, }}$ measurement uncertainty of \pm 0.4 bar). The hydrogen volume flow is measured by a gas flow meter (measurement range of $0-100 \mathrm{I}_{\mathrm{N}} / \mathrm{min}$ extendable to $130 \mathrm{I}_{\mathrm{N}} / \mathrm{min}$, measurement uncertainty of $\pm(0.5 \% \mathrm{Rd}+0.1 \% \mathrm{FS}))$. The used heat transfer fluid is SilOil M40.165/220.10 by Huber Kältemaschienenbau AG (Germany). Its thermal capacity was measured at our institute with the differential scanning calorimetry method and is given as $c_{p . H T F}\left[\frac{\mathrm{J}}{g K}\right]=0.0013 \mathrm{~T}\left[{ }^{\circ} \mathrm{C}\right]+1.6718$. The accuracy of the measurement is $\pm 10 \%$. The most important value is the thermal power actually transferred to the heat transfer fluid. This is calculated by the temperature difference of the HTF before $\left(T_{H T F, \text { in }}\right)$ and after $\left(T_{H T F, o u t}\right)$ flowing through the reactor, the mass flow $\left(\dot{m}_{H T F}\right)$ and the thermal capacity of the HTF $\left(c_{p, H T F}\right)$. The thermal power in $\mathrm{W}$ is calculated according to the following equation:

$$
P=\dot{m}_{H T F} c_{p, H T F}\left(T_{H T F, o u t}-T_{H T F, \text { in }}\right)
$$

The overall heat in J released by the system is calculated by integrating the thermal power over time as given in equation (3).

$$
Q=\int_{t=0}^{t} P d t
$$

By knowing the mass of metal hydride and the reaction enthalpy the hydrogen conversion can be calculated in wt. $-\%$ by equation (4):

$$
x=\frac{m_{H 2}}{m_{M H}} \cdot 100
$$

The absorption enthalpy of $\mathrm{LaNi}_{4.85} \mathrm{Al}_{0.15}$ is $31.6 \mathrm{~kJ} / \mathrm{mol}_{\mathrm{H} 2}[29$ ].

An experiment consists of two half-cycles: regeneration and heat production. For regeneration, the thermostat tempering reactor 1 is set to the given regeneration temperature. The regeneration 
temperature of the open system was set to $130^{\circ} \mathrm{C}$ in analogy to the reference experiment of the closed system for better comparison. While the regeneration pressure of the the closed system is set by keeping reactor 2 to ambient temperature, reactor 1 in the open system desorbs against ambient pressure. As soon as all temperatures are at steady-state, the valve either to reactor 2 (closed system) or to the ambient at ambient pressure (open system) is opened. The regeneration is over as soon as the pressure value is at steady-state. Then the valve is closed and reactor 1 is also tempered to ambient temperature. The heat production experiment can start when all temperatures are at the simulated ambient temperature (e.g. $-20^{\circ} \mathrm{C}$ ) in steady-state. The valve is opened to either reactor 2 (closed system) or the hydrogen gas cylinder via a mechanical pressure regulator (open system).

For the initial filling of the closed system with hydrogen, reactor 2 was tempered to $10^{\circ} \mathrm{C}$ and provided with hydrogen at pressure of 20.8 bar until equilibrium was reached. Reactor 1 was evacuated at $50^{\circ} \mathrm{C}$ for 0.5 hours.

Different parameters were varied in order to investigate their influence on the thermal power output. The experiments were conducted in a mixed order and some were repeated to minimize systematic errors. The ambient temperature, the mass flow of the HTF and the supply pressure for the open system or regeneration temperature for the closed system, respectively, were varied. The variation ranges are given in Error! Reference source not found. in section 3.5.

\section{Results and Discussion}

\subsection{Repeatability}

One reference experiment for both systems was repeated several times throughout the experimental period in order to check whether there are errors in the measurement itself or changes inside the material over time. The results in terms of pressure course, thermal power and hydrogen conversion are shown in Error! Reference source not found..

For the closed system (Error! Reference source not found., left) the reference experiment is performed at ambient temperature of $-20^{\circ} \mathrm{C}$, regenerated with at waste heat temperature of $130^{\circ} \mathrm{C}$ and a HTF mass flow of $250 \mathrm{~kg} / \mathrm{h}$. The course of the pressure and the thermal power are very similar. In experiment 2 (green solid line) a little higher peak value of $0.62 \mathrm{~kW}$ is reached compared to 0.58 and $0.56 \mathrm{~kW}$ of the other two experiments (10 and 16), but it is still within the same range. The integration of the reached power level over the measurement duration leads to similar courses and end values for the hydrogen conversion. Therefore, it can be stated that no changes occurred in the material and inside the reactor and thus the experiments are repeatable.

The reference experiment for the open system (Error! Reference source not found., right) is conducted at $-20^{\circ} \mathrm{C}$, a HTF mass flow of $250 \mathrm{~kg} / \mathrm{h}$ and supply pressure of $1.6 \mathrm{bar}$. Again, the pressure course is very similar for each experiment. The measured peak thermal power values are between 1.34 and $1.43 \mathrm{~kW}$. This variance is small and the curves still lie close together. Nevertheless, it causes a difference in the hydrogen conversion, which is obtained by integrating the thermal power over time. Since no general trend can be observed, it shows rather the sensitivity of the system to operation conditions. Still, since no significant changes in the material and the reactor are observed, the experiments with the open system are repeatable. 


\subsection{Closed system}

For the closed system, the regeneration temperature, mass flow of the HTF and ambient temperature were varied in order to investigate their influence on the thermal peak and average power. The endothermal desorption in reactor 2 (storage reactor) causes a temperature decrease which leads to an additional cooling power. Its value is a little smaller than the one of the heating power due to the smaller desorption enthalpy of $\mathrm{C}^{\circledR}{ }^{\circledR}\left(\Delta \mathrm{H}=28.4 \mathrm{~kJ} / \mathrm{mol}_{\mathrm{H} 2}\right.$ [30]). Nonetheless, this cooling power could probably be utilized for cooling purposes (e.g. air-conditioning) - in any case it needs to be taken into account for system integration.

For ambient temperature of $-20^{\circ} \mathrm{C}$ and $0^{\circ} \mathrm{C}$ the regeneration temperature was varied between 90 and $130^{\circ} \mathrm{C}$. In all cases the HTF mass flow was set to $250 \mathrm{~kg} / \mathrm{h}$. The resulting thermal power and hydrogen conversion are shown in Error! Reference source not found.. For ambient temperature of $20^{\circ} \mathrm{C}$ (Error! Reference source not found. (a)), there is no significant difference evident in the course of both the thermal power and hydrogen conversion. The peak values for thermal power and hydrogen conversion at ambient temperature of $-20^{\circ} \mathrm{C}$ are $0.58 \mathrm{~kW}$ and $1.06 \mathrm{wt} .-\%$ at regeneration temperature of $90^{\circ} \mathrm{C}$ and $0.58 \mathrm{~kW}$ and $1.10 \mathrm{wt} . \%$ at $130^{\circ} \mathrm{C}$. For ambient temperature of $0^{\circ} \mathrm{C}$ (Error! Reference source not found. (b)) the course of thermal power and hydrogen conversion for regeneration temperatures of 110 and $130^{\circ} \mathrm{C}$ are very similar. The thermal power curves for regeneration temperature for $90^{\circ} \mathrm{C}$ reach lower peak values and decrease earlier and the hydrogen conversion reaches a smaller end value indicating the $90^{\circ} \mathrm{C}$ might not be sufficient for complete regeneration. For ambient temperature of $0^{\circ} \mathrm{C}$ the peak values are $1.05,1.08$ and $1.09 \mathrm{~kW}$ with 0.84 , 1.07 and $1.10 \mathrm{wt} .-\%$ of exchanged hydrogen at regeneration temperatures of 90,110 and $130^{\circ} \mathrm{C}$, respectively.

The experimental results show the following. At $-20^{\circ} \mathrm{C}$, a regeneration temperature of $90^{\circ} \mathrm{C}$ or a temperature difference of $110 \mathrm{~K}$ is sufficient since increasing the regeneration temperature doesn't have an impact on the thermal power. At $0^{\circ} \mathrm{C}$ a regeneration temperature of $110^{\circ} \mathrm{C}$ is necessary to reach the highest thermal power values. Further increase doesn't improve thermal power. Therefore a certain temperature difference independent of ambient temperature has to be exceeded for complete regeneration, in the present case this value is around $110 \mathrm{~K}$. A further increase doesn't have any positive impact on the performance of the storage. The required difference is actually determined by the chosen metal hydride pair. Their distance in the Van't Hoff-plot (see Error! Reference source not found.) defines the required temperature difference to reach a higher pressure in reactor 1 than in reactor 2 for regeneration. For the application in vehicles, this means that in winter, a lower waste heat temperature from the engine for regeneration is sufficient for a complete regeneration as compared to summer conditions.

Besides the regeneration temperature, the mass flow of the HTF was varied between 150 and $250 \mathrm{~kg} / \mathrm{h}$ for ambient temperature of $-20^{\circ} \mathrm{C}$ and between 150 and $425 \mathrm{~kg} / \mathrm{h}$ for ambient temperature of $20^{\circ} \mathrm{C}$. The resulting thermal power and hydrogen conversion are shown in Error! Reference source not found.. At an ambient temperature of $-20^{\circ} \mathrm{C}$ (Error! Reference source not found. (a)) no deviation is evident in thermal power or hydrogen conversion and the thermal power reaches peak values of about $0.6 \mathrm{~kW}$. At ambient temperature of $20^{\circ} \mathrm{C}$ (Error! Reference source not found. (b)) the peak thermal power of reactor 1 increases from $1.2 \mathrm{KW}$ for $150 \mathrm{~kg} / \mathrm{h}$ to $1.5 \mathrm{~kW}$ for $250 \mathrm{~kg} / \mathrm{h}$ and reaches the highest values of $1.7 \mathrm{~kW}$ for a HTF flow of $425 \mathrm{~kg} / \mathrm{h}$. The hydrogen conversion curve is steeper for higher HTF mass flows but all reach the similar end value of about 1 wt.-\%. 
The following conclusions can be drawn from these experimental findings. The overall hydrogen conversion is independent of the HTF mass flow in the investigated ranges. Only the development over time at low mass flow rates and high ambient temperatures show small sensitivity. In general the mass flow seems to have an influence on the thermal power at higher ambient temperatures where thermal power values are comparably high (indicating a limitation due to the test facility). At $-20^{\circ} \mathrm{C}$ the peak thermal power of $0.6 \mathrm{~kW}$ can be conducted sufficiently by HTF mass flow of $150 \mathrm{~kg} / \mathrm{h}$. At $20^{\circ} \mathrm{C}$ the power increases significantly with the mass flow, indicating an influence of the HTF mass flow on the overall heat transfer in the reactor at high thermal power values. Because the high thermal power is obviously ensured by the other influence factors (especially reaction rate), its value reached by the metal hydride couple operated at moderate temperatures might still be increased. However, for low temperature, the power density of the closed system seems to be intrinsically limited. This is discussed further in section 3.4.

In Figure 7, the pressure gradient, the thermal power of reactor 1 and the hydrogen conversion is given for experiments with varying ambient temperature $\left(T_{\text {reg }}=130^{\circ} \mathrm{C}, 250 \mathrm{~kg} / \mathrm{h}\right.$ mass flow of HTF) . The pressure drops considerably with decreasing ambient temperature. At $20^{\circ} \mathrm{C}$ the peak pressure value is $2.5 \mathrm{bar}$, at $0^{\circ} \mathrm{C}$ it is around $1 \mathrm{bar}$ and at $-20^{\circ} \mathrm{C}$ it is around $400 \mathrm{mbar}$ with a peak value of 614 mbar after $321 \mathrm{~s}$. A strong dependency on the ambient temperature is evident both in the thermal power and in the course of hydrogen conversion. Correspondingly, the peak values of thermal power increase from $0.58 \mathrm{~kW}$ for $-20^{\circ} \mathrm{C}$ ambient temperature to $1.1 \mathrm{~kW}$ at $0^{\circ} \mathrm{C}$ to $1.55 \mathrm{~kW}$ for $20^{\circ} \mathrm{C}$. The end value of hydrogen conversion at $600 \mathrm{~s}$ is comparable for all experiments $(1.10,1.10$ and $1.03 \mathrm{wt.} . \%$ for $-20,0$ and $20^{\circ} \mathrm{C}$, respectively). The maximal temperature rise of the HTF was $5 \mathrm{~K}$ at $-20^{\circ} \mathrm{C}$ and $12 \mathrm{~K}$ at $20^{\circ} \mathrm{C}$. These experiments were additionally conducted for different values for regeneration temperature and HTF mass flow (see Error! Reference source not found.). In all cases the results follow the trend described here.

As in the closed system the same ambient temperature applies to reactor 1 and to reactor 2 , the pressure of the provided hydrogen changes as well. Therefore, both equilibrium pressures in the reactors decrease with ambient temperature. Even though, the pressure difference between the reactors doesn't change much for the different ambient temperatures, the operation pressure of the system drops below 1 bar at $-20^{\circ} \mathrm{C}$. This might limit the mass transfer in the system and therefore the reaction. Another possibility might be reduced reaction kinetics of either one of the materials at lower temperatures. This point is discussed further in section 3.4 at the comparison of the open and the closed system.

In the following, the open system is investigated where - in contrary to the experiments with the closed system - the supply pressure is independent from the ambient temperature since it can be taken at a constant pressure from the hydrogen tank.

\subsection{Open system}

For the open system the influence of the supply pressure, the HTF mass flow and the ambient temperature on the thermal power were investigated by systematic variation of the experimental conditions.

The supply pressure was varied between 1.5 and 10.0 bar for an ambient temperature of $-20^{\circ} \mathrm{C}$ and between 1.5 and 2.9 bar for an ambient temperature of $0^{\circ} \mathrm{C}$. The resulting thermal power and 
hydrogen conversion are shown in Error! Reference source not found.. For both simulated ambient temperatures the thermal power increases significantly with supply pressure both in slope and peak value. The reached peak values for $-20^{\circ} \mathrm{C}$ are $1.39 \mathrm{~kW}$ at 1.5 bar, $2.56 \mathrm{~kW}$ at 3 bar and $5.14 \mathrm{~kW}$ at 10 bar, respectively. For $0^{\circ} \mathrm{C}$ they are $1.02 \mathrm{~kW}$ at 1.5 bar and $2.11 \mathrm{~kW}$ at 2.9 bar, respectively. The hydrogen conversion increases faster, reaches higher values and the heat production stops consequently earlier with increasing supply pressure. The maximal temperature increase of the HTF at $-20^{\circ} \mathrm{C}$ was $12 \mathrm{~K}$ at 1.5 bar and $43 \mathrm{~K}$ at 10 bar.

Since in the open system the supply pressure can be adjusted independently from the ambient temperature, an increasing supply pressure increases intrinsically the distance to the equilibrium pressure of the material in reactor 1 . This explains the increase in thermal power. Another effect could be that the mass transfer limitation through the bed (as mentioned in 2.3) decreases with increasing pressure.

The mass flow of HTF was varied, too. Here, no significant trend was obvious. For peak values it is referred to Error! Reference source not found. in section 3.5.

The ambient temperature was varied between -20 and $20^{\circ} \mathrm{C}$ for a supply pressure of 3 bar and between -20 and $0^{\circ} \mathrm{C}$ for a supply pressure of 1.5 bar. For all experiments the HTF mass flow was $250 \mathrm{~kg} / \mathrm{h}$. The results of thermal power and hydrogen conversion are given in Error! Reference source not found.. The trends are the same for both supply pressures. The thermal power decreases with higher ambient temperature and the time of heat supply increases. The peak values for $3 \mathrm{bar}$ are $2.56,2.11$ and $1.51 \mathrm{~kW}$ for $-20,0$ and $20^{\circ} \mathrm{C}$, respectively, and 1.39 and $1.02 \mathrm{~kW}$ for -20 and $0^{\circ} \mathrm{C}$, respectively, for 1.5 bar. A similar trend is evident in the hydrogen conversion. For higher ambient temperatures the slope decreases and it takes more time to reach the final value. Once the reaction is over, the final values of the hydrogen conversion are very similar for each supply pressure value.

At a first glance, these findings of decreasing thermal power at increasing temperature seem to be in contradiction to Arrhenius's law. However, since the supply pressure is fixed a decrease of the reaction temperature leads to a higher distance to the equilibrium pressure. Therefore, it can be stated for this set-up that the distance to the equilibrium has a stronger impact on thermal power than the ambient temperature itself.

\subsection{Comparison of open and closed system}

The comparison of open and closed system under same conditions is challenging due to the different courses of the system pressure. However, in order to be able to investigate the influence of reactor 2, a comparison of pressure, hydrogen flow into reactor 1 and thermal power are given in Error! Reference source not found. as a function of the ambient temperature.

At an ambient temperature of $20^{\circ} \mathrm{C}$ (Error! Reference source not found., left) the supply pressure for the open system was set to 3 bar which causes a similar pressure at $30 \mathrm{~s}$ as in the closed system (Even though the initial pressure in the closed system is $14 \mathrm{bar}$ ). The course of the pressure after $30 \mathrm{~s}$ is very different. However, the resulting thermal power is similar, at least at the beginning and reaches similar peak values with slightly higher value for the closed system ( $1.54 \mathrm{~kW})$ than for the open system (1.51 kW). The thermal power of the closed system decreases slightly faster.

At ambient temperature of $0^{\circ} \mathrm{C}$ (Error! Reference source not found., middle) the supply pressure for the open system was set to 1.5 bar (the initial pressure in the closed system was 7.9 bar). Even 
though the thermal power of the closed system increases faster the general trend is comparable between the open and closed system. The hydrogen volume flow is similar but decreases again slightly faster for the closed system.

At ambient temperature of $-20^{\circ} \mathrm{C}$ (Error! Reference source not found., right) the supply pressure for the open system was set to 1.5 bar (the initial pressure in the closed system was 4.3 bar). The pressure increases faster for the open system and reaches its maximal value of 1.4 bar after $600 \mathrm{~s}$ not changing significantly after $300 \mathrm{~s}$. In the closed system the pressure is rather constant with a slow increase to a maximal value of 0.6 bar after around $340 \mathrm{~s}$ before it drops again. The hydrogen flow increases steeply for both systems and reaches a peak value of $77 I_{N} / \mathrm{min}$ for the closed and $65 \mathrm{I}_{N} / \mathrm{min}$ for the open system. The very sharp peak at the beginning of the experiment with the closed system is due to the equalization of the gas pressure inside the void fraction. The most interesting point of the comparison can be observed after this equalization when it decreases quickly to a value of only around $20 I_{N} / \mathrm{min}$ and continues to decrease parallel to the thermal power until the end of the experiment.

From these comparisons it can be concluded that for temperatures of $20^{\circ} \mathrm{C}$ and $0^{\circ} \mathrm{C}$ similar hydrogen flow and pressure courses lead to similar thermal power generation. Obviously, the open system could be adjusted to even higher power levels - due to the additional degree of freedom that comes with the independency of the supply pressure from the ambient temperature. However, the results for $-20^{\circ} \mathrm{C}$ show totally different curves of hydrogen flow and thermal power. In the closed system after the first seconds the hydrogen flow is much lower, leading to smaller pressure and thermal power values. Therefore, the limited thermal power in the closed system seems to be caused by the limited reaction rate of the metal hydride in reactor 2 at $-20^{\circ} \mathrm{C}$ and low pressure. Since these types of metal hydrides are in general supposed to possess very fast reaction kinetics [24] this finding has to be confirmed in future work on reaction rate measurements at these temperature and pressure conditions.

\subsection{General discussion}

A summary of all experiments, including the boundary conditions, thermal power, thermal energy and hydrogen conversion for the closed and open system is given in Error! Reference source not found. The probable error for the thermal power was $\pm 10.6 \%$ with a standard deviation of $0.5 \%$. High thermal power could be shown for both systems even though the open system is able to reach clearly higher values. In order to generalize the findings, the values are normalized and given per $\mathrm{kg}$ metal hydride. The closed system reached values between $0.6 \mathrm{~kW} / \mathrm{kg}_{\mathrm{MH}}$ at ambient temperature of $-20^{\circ} \mathrm{C}$ and $1.6 \mathrm{~kW} / \mathrm{kg}_{\mathrm{MH}}$ at $20^{\circ} \mathrm{C}$, at otherwise same conditions. The open system reached $1.4 \mathrm{~kW} / \mathrm{kg}_{\mathrm{MH}}$ at $-20^{\circ} \mathrm{C}$ and supply pressure of 1.5 bar and $5.4 \mathrm{~kW} / \mathrm{kg}_{\mathrm{MH}}$ at $-20^{\circ} \mathrm{C}$ and 10 bar.

It is obvious that the investigations were performed with comparably heavy reactors of $2.09 \mathrm{~kg}$. The ratio of mass of metal hydride to mass of reactor are $1: 2.2$ for reactor 1 and $1: 3.4$ for reactor 2 . However, the given experimental values include the thermal mass and temperature change of the materials, containing reactors and HTF. Still high values are achieved, because of the high thermal energy density of the material, therefore showing high potential especially for mobile applications. In general, due to the "switchable" operation principle, it can be suggested to integrate the reacting 
material directly into the respective component. In this case, the additional heat transfer with a HTF can be avoided and the full thermal power is available at the point of demand.

In order to compare the results with the state of the art, the best comparable work in literature to the best of our knowledge, is discussed in the following.

Little work is found in literature for preheating fuel cells with the help of metal hydrides. Docter et al. [31] published a patent considering metal hydrides to shorten cold-start phase. TiFe is proposed for the application at temperatures between $-30^{\circ} \mathrm{C}$ and $50^{\circ} \mathrm{C}$. Unfortunately no experimental data is provided. Brack [32] investigated $\mathrm{LaNi}_{4.1} \mathrm{Al}_{0.52} \mathrm{Mn}_{0.38}$ designed for direct integration into a high temperature PEM fuel cell operating at clearly higher temperatures $\left(100-170^{\circ} \mathrm{C}\right)$. The maximal thermal power output reached $5.7 \mathrm{~kW} / \mathrm{kg}_{\mathrm{MH}}$ which is comparable to the power density reached in this work.

Some work was presented in literature concerning coupled metal hydride reactions. Fang et al. [33] investigated coupled catalyzed $\mathrm{MgH}_{2}-\mathrm{TiV}_{0.62} \mathrm{Mn}_{1.5}$ for heating and cooling of cabins in electric vehicles. Some boundary conditions differ to the presented study (regeneration temperature level of $270^{\circ} \mathrm{C}$, material partly combined with expanded natural graphite, ambient temperature of $20^{\circ} \mathrm{C}$ ) which limits comparability. The resulting thermal peak power of $320 \mathrm{~W}$ occurs only after about $2 \mathrm{~min}$ which limits the applicability for quick ramp-up or start-up applications. Aswin et al. [16] considered coupled metal hydrides in the temperature range of $30-80^{\circ} \mathrm{C}$. The work focuses on the simulation of coupled reactions and shows the possible fast reaction rates but no experiments were conducted.

The present work could experimentally show high thermal power densities of metal hydrides under automotive boundary conditions both for the open and coupled reactions. Therefore, the presented principle can meet the requirements for the considered applications in vehicles. In order to understand the observed limitations in more detail, in particular for coupled chemical reaction at low temperatures and pressures, further research is necessary. Detailed material characterizations at these conditions are therefore planned as subsequent work.

\section{Conclusions}

In this paper metal hydrides as candidates for thermochemical energy storage were investigated with regard to providing their high thermal power for preheating e.g. vehicle components applications. To shorten the cold start phase considerably, high thermal power is needed. Operation designs for open and closed systems were developed, materials selected and reactors and a test bench built to investigate influence factors on the thermal power. $\mathrm{LaNi}_{4.85} \mathrm{Al}_{0.15}$ was used for the heat producing side and Hydralloy $\mathrm{C}^{\circledR}$ was used for the hydrogen storage side in the closed system. Main unique features are investigations of the closed system with coupled chemical reactions, temperatures down to $-20^{\circ} \mathrm{C}$ and relevant scale for vehicle applications. The mass flow of the heat transfer fluid (varied range $150 \ldots 425 \mathrm{~kg} / \mathrm{h})$, the regeneration conditions for the closed system $\left(90 \ldots 130^{\circ} \mathrm{C}\right)$ and the supply pressure for the open system $(1.5 \ldots 10 \mathrm{bar})$ as well as the ambient temperature $\left(-20 \ldots 20^{\circ} \mathrm{C}\right)$ were varied.

- It was found that for the closed system, a certain temperature difference has to be reached for complete regeneration. Since this might already limit the integration possibilities, further increase of the distance of the thermodynamic values of the metal hydrides (distance in 
Van't Hoff plot, see Error! Reference source not found.) is not advantageous. The closed system reached values between $0.6 \mathrm{~kW} / \mathrm{kgMH}$ at ambient temperature of $-20^{\circ} \mathrm{C}$ and 1.6 $\mathrm{kW} / \mathrm{kgMH}$ at $20^{\circ} \mathrm{C}$, at otherwise same conditions.

- In the open system, the ambient temperature is of importance only in relation to the available supply pressure. The distance of the supply pressure to the pressure equilibrium of the chosen material at the highest considered ambient temperature has to be large enough. The open system reached $1.4 \mathrm{~kW} / \mathrm{kgMH}$ at $-20^{\circ} \mathrm{C}$ and supply pressure of $1.5 \mathrm{bar}$ and $5.4 \mathrm{~kW} / \mathrm{kgMH}$ at $-20^{\circ} \mathrm{C}$ and $10 \mathrm{bar}$. Therefore, for the open system, the material selection for the given boundary conditions is most important.

- For the heat production with thermochemical systems the ambient temperature has the biggest influence. For the closed system the thermal power directly correlates with the ambient temperature. This might be attributed to limitations of desorption kinetics at low temperatures, but need to be confirmed in subsequent analysis. The open system can bypass this restriction, because it has an additional degree of freedom in the hydrogen pressure. Hence, depending on the chosen material and supply pressure, higher thermal power can be reached.

\section{Acknowledgments}

Our thanks go to Christian Brack and Mei Chin Pang for her supportive work as well as to Alexander Bonk and Stephanie Kraft for the measurement of the heat capacity of the HTF.

\section{References}

[1] Reiter MS, Kockelman KM. The problem of cold starts: A closer look at mobile source emissions levels. Transp Res Part D Transp Environ 2016;43:123-32. doi:10.1016/j.trd.2015.12.012.

[2] Cipollone R, Di Battista D, Mauriello M. Effects of Oil Warm up Acceleration on the Fuel Consumption of Reciprocating Internal Combustion Engines. Energy Procedia 2015;82:1-8. doi:10.1016/j.egypro.2015.11.870.

[3] Mishler J, Wang Y, Mukherjee PP, Mukundan R, Borup RL. Subfreezing operation of polymer electrolyte fuel cells: Ice formation and cell performance loss. Electrochim Acta 2012;65:12733. doi:10.1016/j.electacta.2012.01.020.

[4] Santamaria A, Tang HY, Park JW, Park GG, Sohn YJ. 3D neutron tomography of a polymer electrolyte membrane fuel cell under sub-zero conditions. Int J Hydrogen Energy 2012;37:10836-43. doi:10.1016/j.ijhydene.2012.04.093.

[5] Lim SJ, Park GG, Park JS, Sohn YJ, Yim SD, Yang TH, et al. Investigation of freeze/thaw durability in polymer electrolyte fuel cells. Int J Hydrogen Energy 2010;35:13111-7. doi:10.1016/j.ijhydene.2010.04.079.

[6] Lin R, Lin X, Weng $Y$, Ren $Y$. Evolution of thermal drifting during and after cold start of proton exchange membrane fuel cell by segmented cell technology. Int J Hydrogen Energy 2015;40:7370-81. doi:10.1016/j.jjhydene.2015.04.045.

[7] Neveu P, Castaing J. Solid-gas chemical heat pumps: field of application and performance of 
the internal heat of reaction recovery process. Heat Recover Syst CHP 1993;13.

[8] Srinivasa Murthy S. Heat and Mass Transfer in Solid State Hydrogen Storage: A Review. J Heat Transfer 2012;134:31020. doi:10.1115/1.4005156.

[9] Mazzucco A, Dornheim M, Sloth M, Jensen TR, Jensen JO, Rokni M. Bed geometries, fueling strategies and optimization of heat exchanger designs in metal hydride storage systems for automotive applications: A review. Int J Hydrogen Energy 2014;39:17054-74. doi:10.1016/j.ijhydene.2014.08.047.

[10] Zhang J, Fisher TS, Ramachandran PV, Gore JP, Mudawar I. A Review of Heat Transfer Issues in Hydrogen Storage Technologies. J Heat Transfer 2005;127:1391. doi:10.1115/1.2098875.

[11] Muthukumar P, Groll M. Metal hydride based heating and cooling systems: A review. Int J Hydrogen Energy 2010;35:3817-31. doi:10.1016/j.ijhydene.2010.01.115.

[12] Bhuiya MMH, Kumar A, Kim KJ. Metal hydrides in engineering systems, processes, and devices: A review of non-storage applications. Int J Hydrogen Energy 2015. doi:10.1016/j.ijhydene.2014.12.009.

[13] Linder M, Mertz R, Laurien E. Experimental results of a compact thermally driven cooling system based on metal hydrides. Int J Hydrogen Energy 2010;35:7623-32. doi:10.1016/j.ijhydene.2010.04.184.

[14] Park I-S, Kim J-K, Kim KJ, Zhang J, Park C, Gawlik K. Investigation of coupled AB5 type highpower metal hydride reactors. Int J Hydrogen Energy 2009;34:5770-7. doi:10.1016/j.ijhydene.2009.05.012.

[15] Imoto T, Yonesaki T, Fujitani S, Yonezu I, Hiro N, Nasako K, et al. Development of an F-class refrigeration system using hydrogen-absorbing alloys. Int J Hydrogen Energy 1996;21:451-5. doi:10.1016/0360-3199(95)00106-9.

[16] Aswin N, Dutta P, Murthy SS. Screening of metal hydride pairs for closed thermal energy storage systems. Appl Therm Eng 2016. doi:10.1016/j.applthermaleng.2016.04.129.

[17] Sharma VK, Anil Kumar E, Srinivasa Murthy S. Influence of dynamic operating conditions on the performance of metal hydride based solid sorption cooling systems. Int J Hydrogen Energy 2015;40:1108-15. doi:10.1016/j.ijhydene.2014.11.084.

[18] Yasuda N, Tsuchiya T, Okinaka N, Akiyama T. Application of metal hydride sheet to thermally driven cooling system. Int J Hydrogen Energy 2013:1-8. doi:10.1016/j.ijhydene.2013.04.011.

[19] $\mathrm{Ni} \mathrm{J,} \mathrm{Liu} \mathrm{H.} \mathrm{Experimental} \mathrm{research} \mathrm{on} \mathrm{refrigeration} \mathrm{characteristics} \mathrm{of} \mathrm{a} \mathrm{metal} \mathrm{hydride} \mathrm{heat}$ pump in auto air-conditioning. Int J Hydrogen Energy 2007;32:2567-72. doi:10.1016/j.ijhydene.2006.09.038.

[20] Dehouche Z, de Jong W, Willers E, Isselhorst A, Groll M. Modelling and simulation of heating/air-conditioning systems using the multi-hydride-thermal-wave concept. Appl Therm Eng 1998;18:457-80. doi:10.1016/S1359-4311(97)00043-4.

[21] Jadhao JS, Thombare DG. Review on Exhaust Gas Heat Recovery for I.C. Engine. Certif. Int. J. Eng. Innov. Technol., vol. 2, 2013, p. 2277-3754.

[22] Klell M. Handbook of Hydrogen Storage. Chapter 1 Storage of Hydrogen in the Pure Form. Wiley-VCH Verlag GmbH \& Co. KGaA; 2010. doi:10.1002/9783527629800.ch1. 
[23] Muthukumar P, Satheesh A, Linder M, Mertz R, Groll M. Studies on hydriding kinetics of some La-based metal hydride alloys. Int J Hydrogen Energy 2009;34:7253-62.

doi:10.1016/j.ijhydene.2009.06.075.

[24] Skripnyuk V, Ron M. Hydrogen desorption kinetics in intermetallic compounds C2, C5 and C5 with Laves phase structure. Int J Hydrogen Energy 2003;28:303-9. doi:10.1016/S03603199(02)00081-2.

[25] Rizvi SQA. A Comprehensive Review of Lubricant Chemistry, Technology, Selection, and Design. ASTM International; 2009.

[26] Lee D-W, Johnson J, Lv J, Novak K, Zeitsman J. Comparisons between vehicular emissions from real-world in-use testing and epa moves estimation. vol. 7. 2012.

[27] Klamann D. Lubricantsand Related Products - Synthesis, Properties, Applications, International Standards. Verlag Chemie GmbH; 1984.

[28] Mitzel J, Gülzow E, Kabza A, Hunger J, Araya SS, Piela P, et al. Identification of critical parameters for PEMFC stack performance characterization and control strategies for reliable and comparable stack benchmarking. Int J Hydrogen Energy 2016;41:21415-26. doi:10.1016/j.ijhydene.2016.08.065.

[29] Selvam PK, Muthukumar P, Linder M, Mertz R, Kulenovic R. Measurement of thermochemical properties of some metal hydrides - Titanium (Ti), misch metal (Mm) and lanthanum (La) based alloys. Int J Hydrogen Energy 2013;38:5288-301. doi:10.1016/j.ijhydene.2013.02.009.

[30] Herbrig K, Röntzsch L, Pohlmann C, Weißgärber T, Kieback B. Hydrogen storage systems based on hydride-graphite composites: computer simulation and experimental validation. Int J Hydrogen Energy 2013;38:7026-36. doi:10.1016/j.ijhydene.2013.03.104.

[31] Docter A, Frank G, Konrad G, Lamm A, Mueller JT. Fuel cell and method for cold-starting such a fuel cell. US 2008/0102327 A1, 2008.

[32] Brack C. Entwicklung, Konstruktion und Fertigung eines Vorheizers für HochtemperaturPolymerelektrolytmembarn-Brennstoffzellen-Systeme auf der Basis von Metallhydriden. Hochschule Zwickau, 2011.

[33] Fang ZZ, Zhou C, Fan P, Udell KS, Bowman RC, Vajo JJ, et al. Metal Hydrides Based High Energy Density Thermal Battery. J Alloys Compd 2015. doi:10.1016/j.jallcom.2014.12.260. 


\section{List of figures}

Figure 1. Van't Hoff Plot of $\mathrm{LaNi}_{4.85} \mathrm{Al}_{0.15}[14]$ and Hydralloy $\mathrm{C} 5^{\circledR}[26]$ including temperature and pressure boundary conditions for the closed (left) and open (right) system Figure 2. Metal hydride reactor in detail

Figure 3. Test bench design with photo (left) and scheme (right)

Figure 4. Repeatability for closed (left; green solid $2^{\text {nd }}$ cycle, red dashed $10^{\text {th }}$ cycle, black dotted $16^{\text {th }}$ cycle) and open system (right; green solid $17^{\text {th }}$ cycle, red dashed $24^{\text {th }}$ cycle, black dotted $26^{\text {th }}$ cycle) Figure 5. Closed system - Variation of regeneration temperature at ambient temperature of (a) $-20^{\circ} \mathrm{C}$ and (b) $0^{\circ} \mathrm{C}$

Figure 6. Closed system - Variation of mass flow of heat transfer fluid at ambient temperature of (a) $20^{\circ} \mathrm{C}$ and (b) $20^{\circ} \mathrm{C}$

Figure 7. Closed System - Variation of ambient temperature

Figure 8. Open system - Variation of pressure for ambient temperature of (a) $-20^{\circ} \mathrm{C}$ and (b) $0^{\circ} \mathrm{C}$

Figure 9. Open System - Variation of ambient temperature with supply pressure of 3 bar (left) and 1.5 bar (right)

Figure 10. Comparison of open (dashed black) and closed (solid red) system for ambient temperature of $20^{\circ} \mathrm{C}$ (left), $0^{\circ} \mathrm{C}$ (middle) and $-20^{\circ} \mathrm{C}$ (right) 


\section{List of tables}

Table 1. Thermal power, thermal energy and conversion for different boundary conditions 


\begin{tabular}{|c|c|c|c|c|c|c|}
\hline \multicolumn{7}{|c|}{ Closed System } \\
\hline $\begin{array}{c}\text { No. of } \\
\text { Experiment }\end{array}$ & $\begin{array}{l}T_{\text {amb }} \\
\text { in }{ }^{\circ} \mathrm{C}\end{array}$ & $\begin{array}{l}T_{\text {reg }} \\
\text { in }{ }^{\circ} \mathrm{C}\end{array}$ & $\begin{array}{c}\dot{m}_{\mathrm{HTF}} \\
\text { in } \mathrm{kg} / \mathrm{h}\end{array}$ & $\begin{array}{c}P_{\text {peak }} \\
\text { in } \mathrm{kW} / \mathrm{kg}\end{array}$ & $\begin{array}{c}Q_{600 \text { sec }} \\
\text { in } \mathrm{kJ} / \mathrm{kg}\end{array}$ & $\begin{array}{c}x_{600 s e c} \\
\text { in wt. }-\%\end{array}$ \\
\hline 8 & \multirow{8}{*}{-20} & \multirow{6}{*}{130} & \multirow{3}{*}{150} & 0.57 & 179.15 & 1.13 \\
\hline 12 & & & & 0.60 & 181.20 & 1.15 \\
\hline 15 & & & & 0.60 & 184.61 & 1.17 \\
\hline 2 & & & \multirow{9}{*}{250} & 0.64 & 178.52 & 1.13 \\
\hline 10 & & & & 0.61 & 173.79 & 1.10 \\
\hline 16 & & & & 0.60 & 167.17 & 1.06 \\
\hline 7 & & 00 & & 0.61 & 167.91 & 1.06 \\
\hline 14 & & 90 & & 0.61 & 169.64 & 1.07 \\
\hline 6 & \multirow{4}{*}{0} & 130 & & 1.14 & 174.22 & 1.10 \\
\hline 4 & & 110 & & 1.14 & 169.61 & 1.07 \\
\hline 13 & & 110 & & 1.11 & 169.11 & 1.07 \\
\hline 3 & & 90 & & 1.09 & 132.08 & 0.84 \\
\hline 5 & \multirow{4}{*}{20} & \multirow{4}{*}{130} & 150 & 1.29 & 162.18 & 1.03 \\
\hline 1 & & & \multirow{2}{*}{250} & 1.61 & 162.65 & 1.03 \\
\hline 11 & & & & 1.58 & 164.23 & 1.04 \\
\hline 9 & & & 425 & 1.78 & 163.04 & 1.03 \\
\hline \multicolumn{7}{|c|}{ Open System } \\
\hline $\begin{array}{c}\text { No. of } \\
\text { Experiment }\end{array}$ & $\begin{array}{l}T_{\text {amb }} \\
\text { in }{ }^{\circ} \mathrm{C}\end{array}$ & $\begin{array}{c}\mathrm{m}_{\mathrm{HTF}} \\
\text { in } \mathrm{kg} / \mathrm{h}\end{array}$ & $\begin{array}{l}\mathbf{p}_{\text {supply }} \\
\text { in bar }\end{array}$ & $\begin{array}{c}P_{\text {peak }} \\
\text { in } \mathrm{kW} / \mathrm{kg}\end{array}$ & $\begin{array}{c}Q_{300 \text { sec }} \\
\text { in } \mathrm{kJ} / \mathrm{kg}\end{array}$ & $\begin{array}{c}x_{300 s e c} \\
\text { in wt.- } \%\end{array}$ \\
\hline 18 & \multirow{6}{*}{-20} & 425 & \multirow{4}{*}{1.5} & 1.55 & 211.15 & 1.34 \\
\hline 17 & & \multirow{9}{*}{250} & & 1.45 & 202.09 & 1.28 \\
\hline 24 & & & & 1.49 & 220.29 & 1.39 \\
\hline 26 & & & & 1.39 & 200.12 & 1.27 \\
\hline 20 & & & 3 & 2.67 & 221.58 & 1.40 \\
\hline 25 & & & 10 & 5.36 & 245.87 & 1.56 \\
\hline 19 & \multirow{3}{*}{0} & & \multirow{2}{*}{1.5} & 1.16 & 200.91 & 1.27 \\
\hline 22 & & & & 1.07 & 202.46 & 1.28 \\
\hline 21 & & & \multirow{2}{*}{3} & 2.20 & 231.45 & 1.46 \\
\hline 23 & 20 & & & 1.57 & 220.66 & 1.40 \\
\hline
\end{tabular}



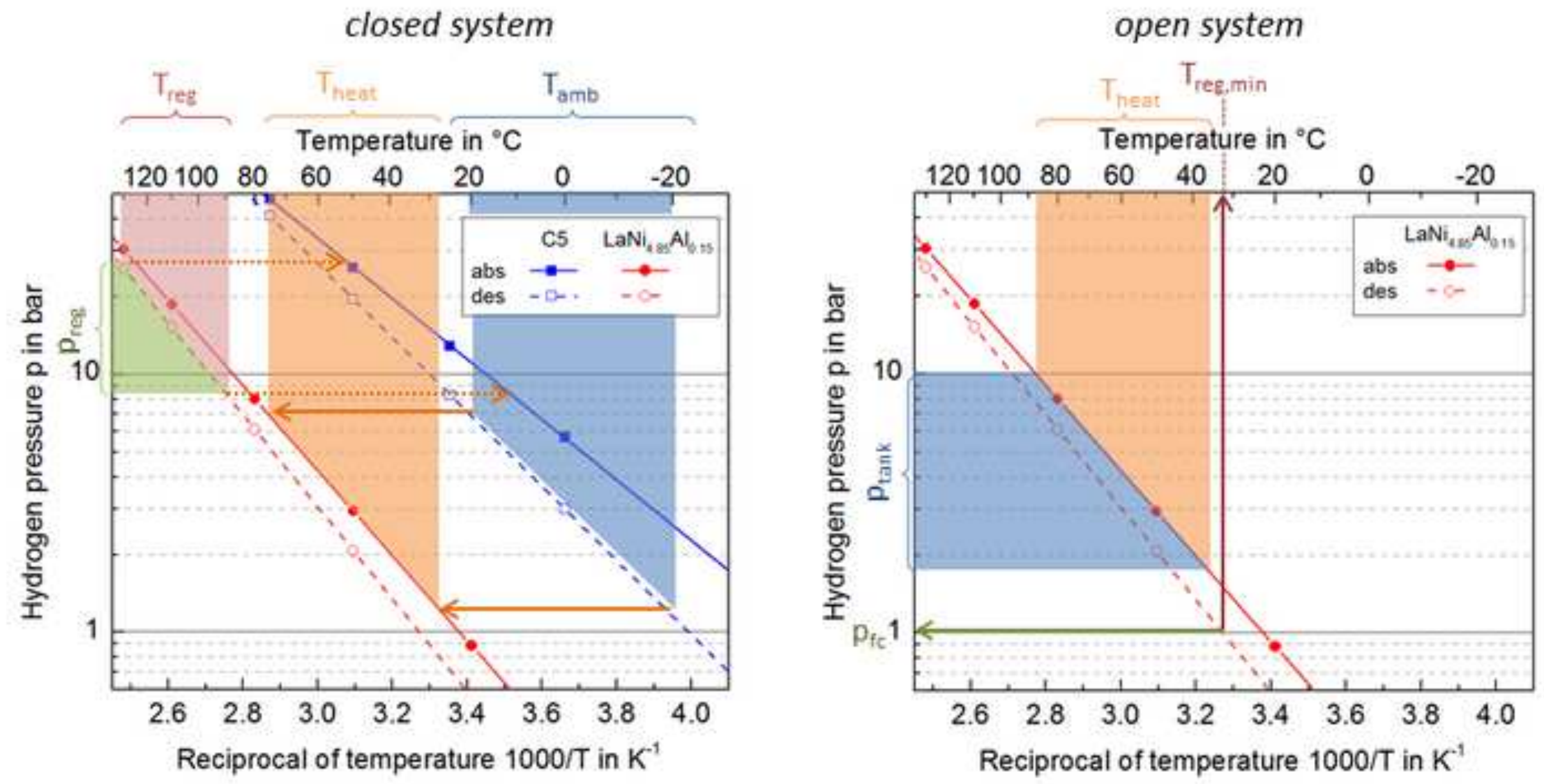


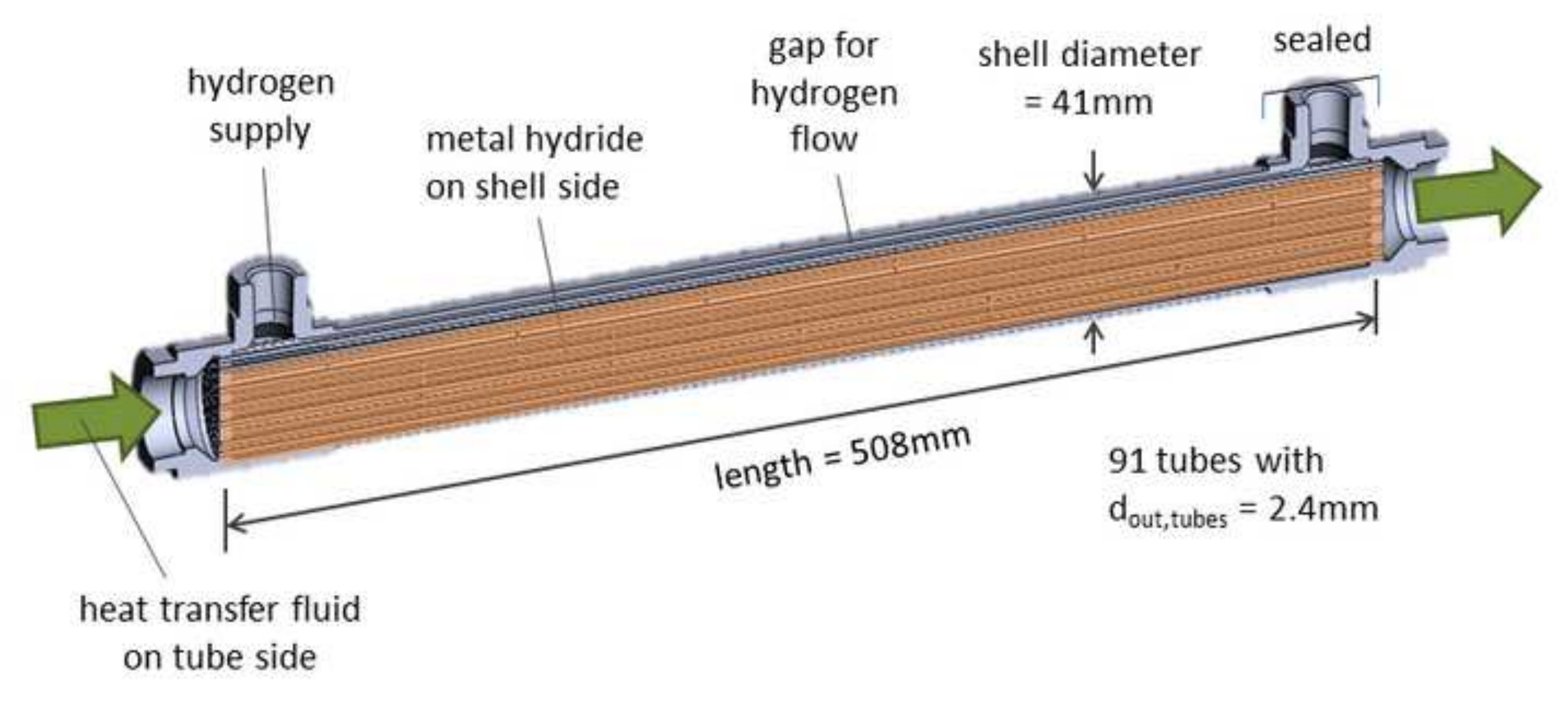

heat transfer fluid

on tube side

(esolution image

91 tubes with

$\mathrm{d}_{\text {out, tubes }}=2.4 \mathrm{~mm}$ gap for diameter sealed ydrogen $\quad=41 \mathrm{~mm}$

flow metal hydride

length $=508 \mathrm{~mm}$

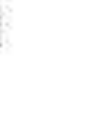

hydrogen

o


Click here to download high resolution image

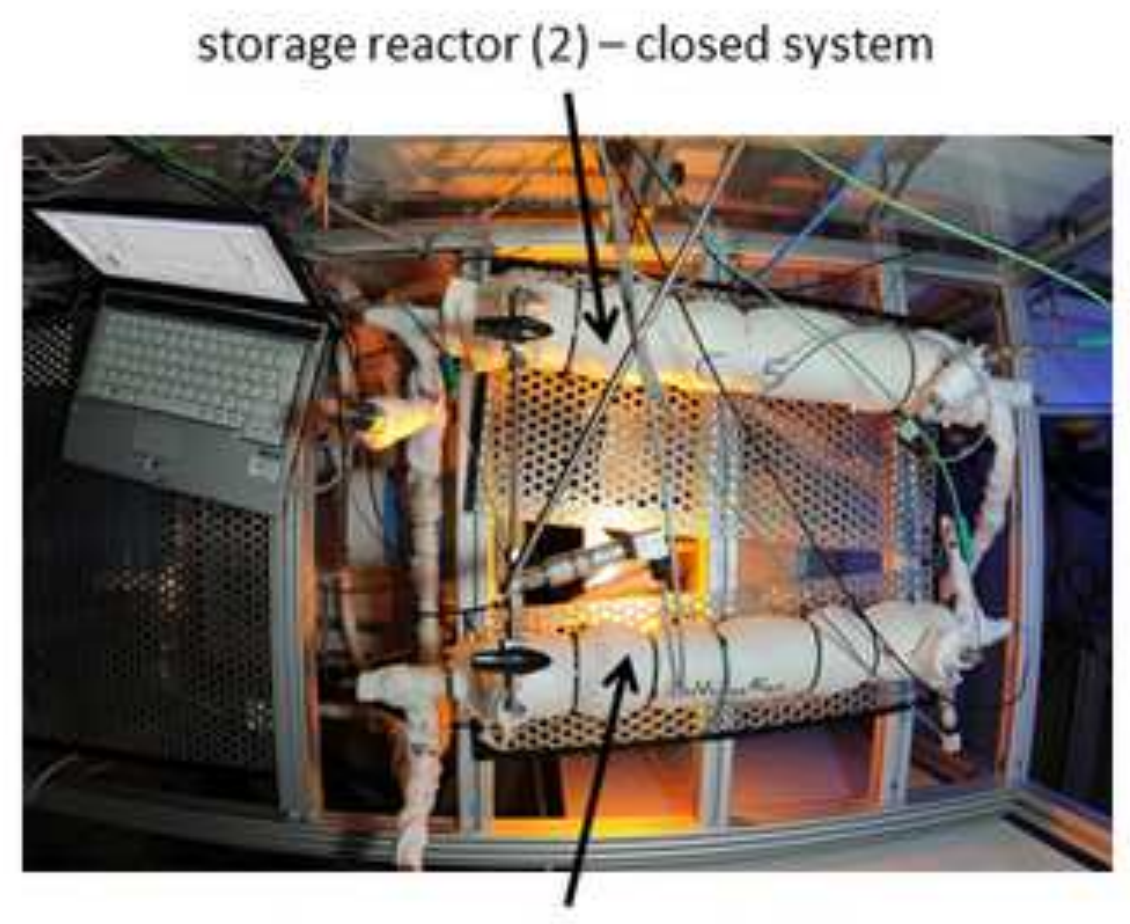

heat generating reactor (1)

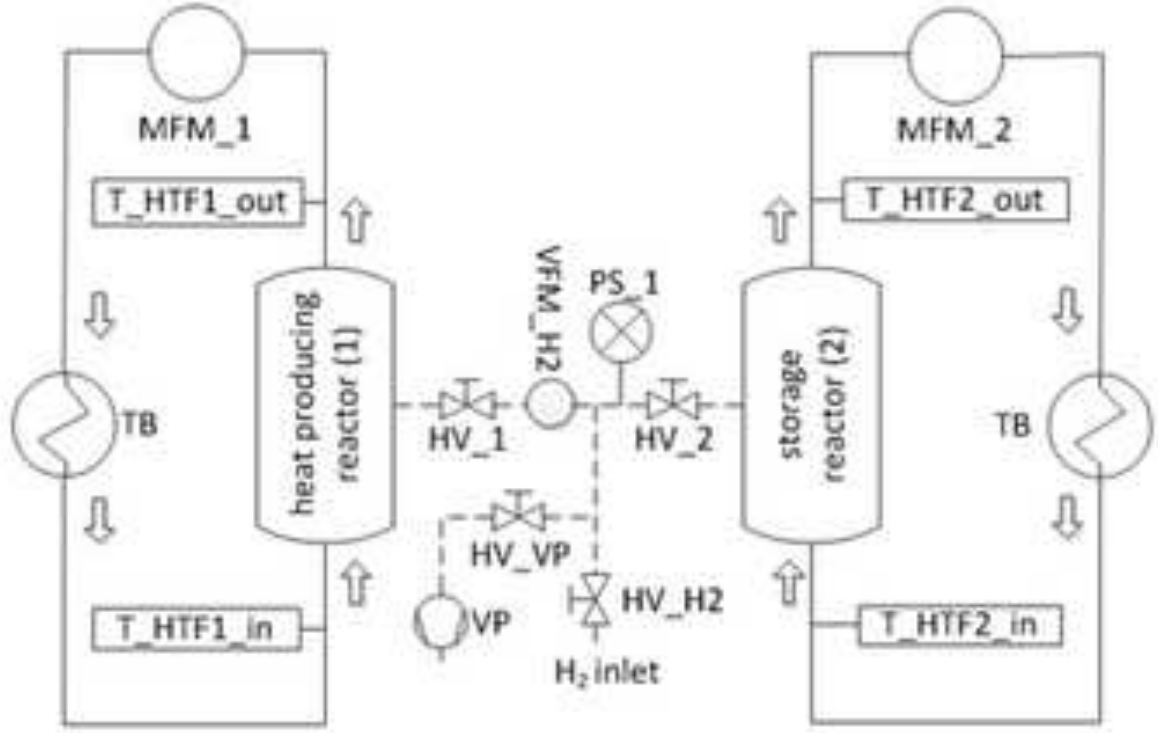

\begin{tabular}{|c|c|c|c|}
\hline \multicolumn{4}{|l|}{ Legend: } \\
\hline HV & hand valve & VFM & hyrogen volume \\
\hline \multirow[t]{2}{*}{ MFM } & heat transfer fluid & & flow meter \\
\hline & mass flow meter & $\mathrm{TB}$ & thermostatic bath \\
\hline \multirow{3}{*}{$\begin{array}{l}\text { PS } \\
\text { T_HTF }\end{array}$} & pressure sensor & VP & vaccum pump \\
\hline & temperature sensor & $\longrightarrow$ & oil pipe \\
\hline & & --- & gas $(\mathrm{H} 2)$-pipe \\
\hline
\end{tabular}

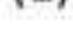


closed system
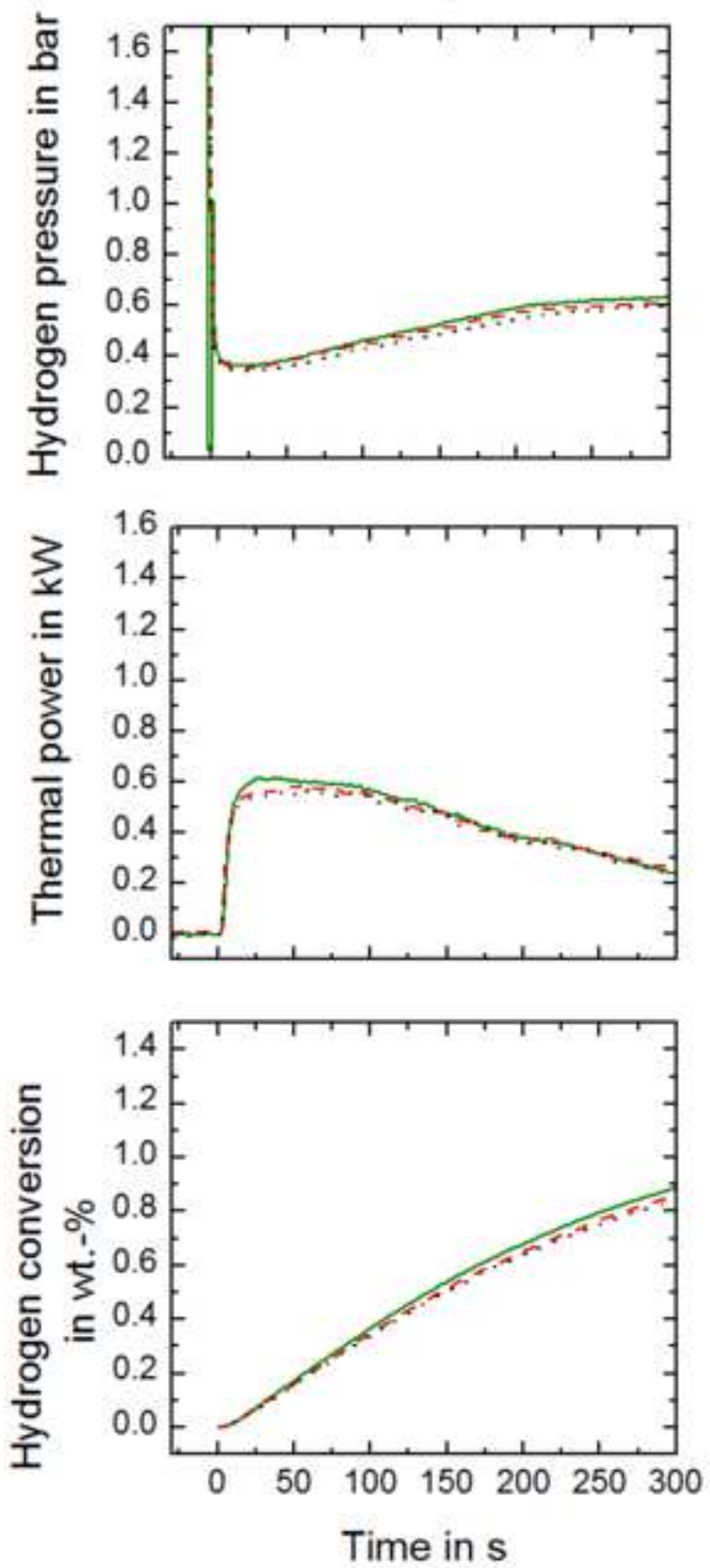

open system
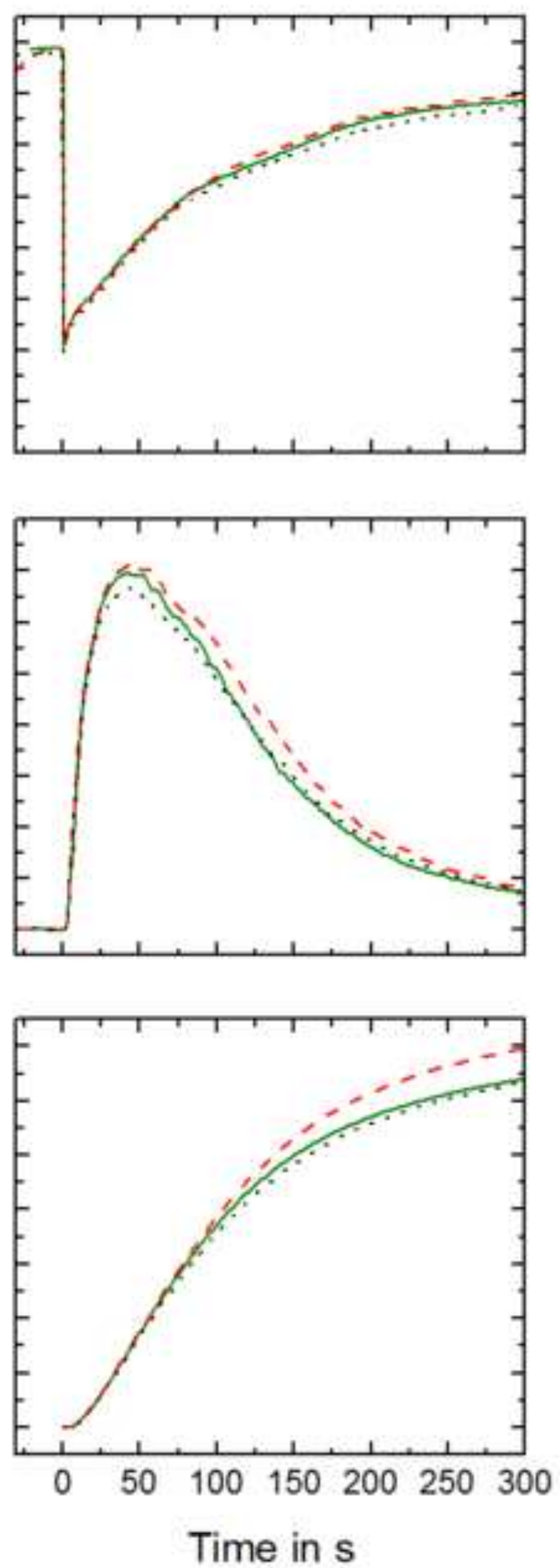

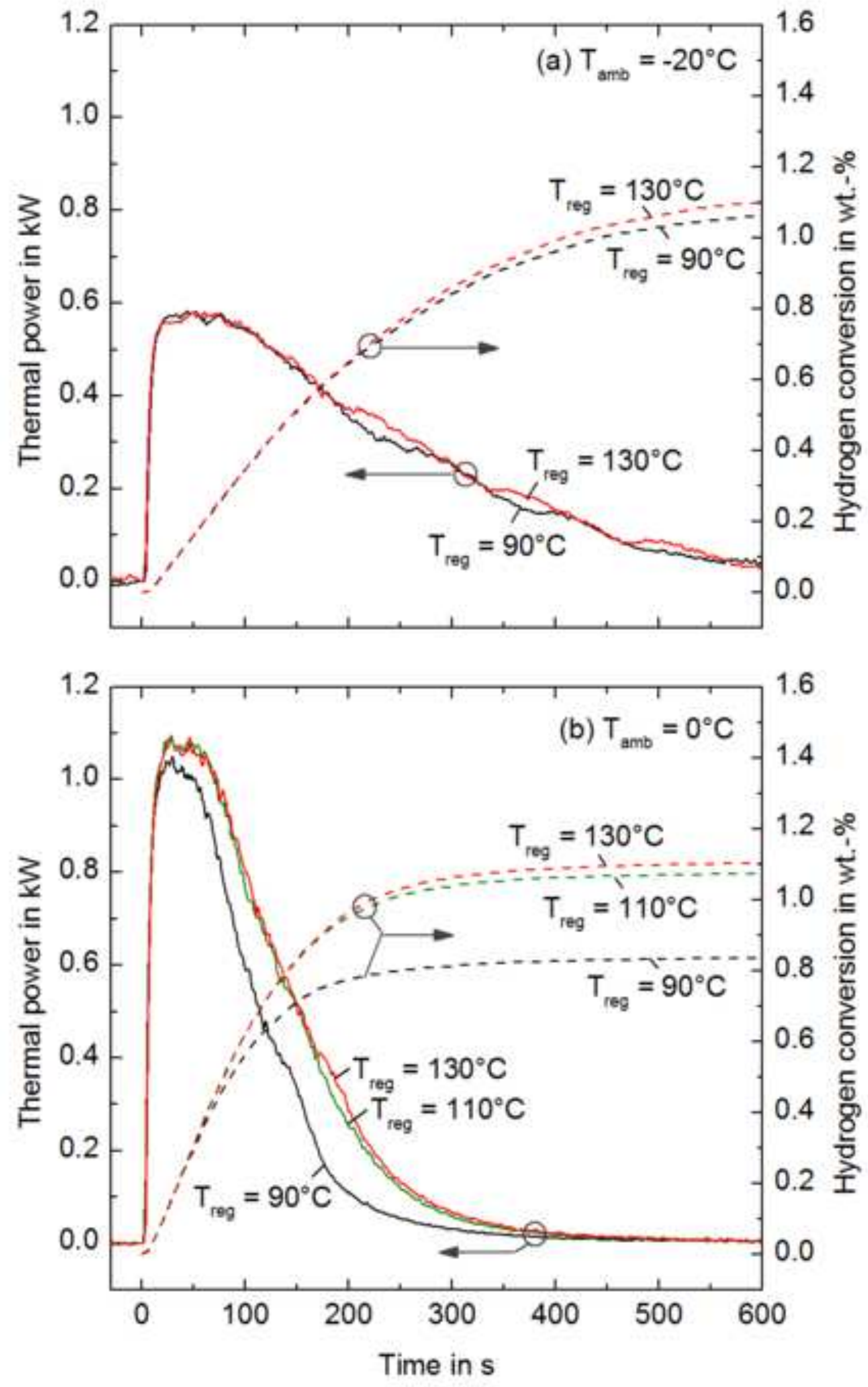

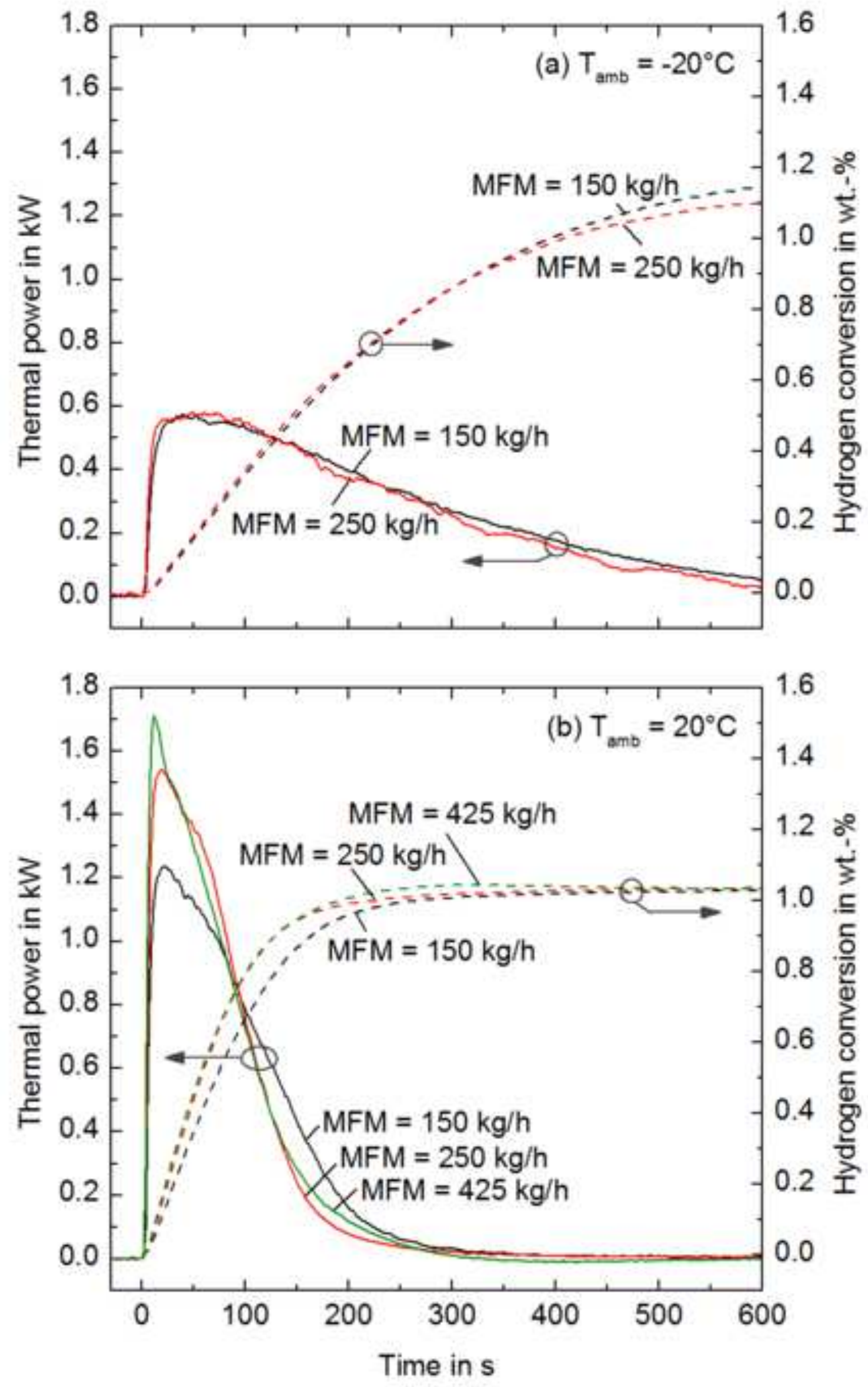

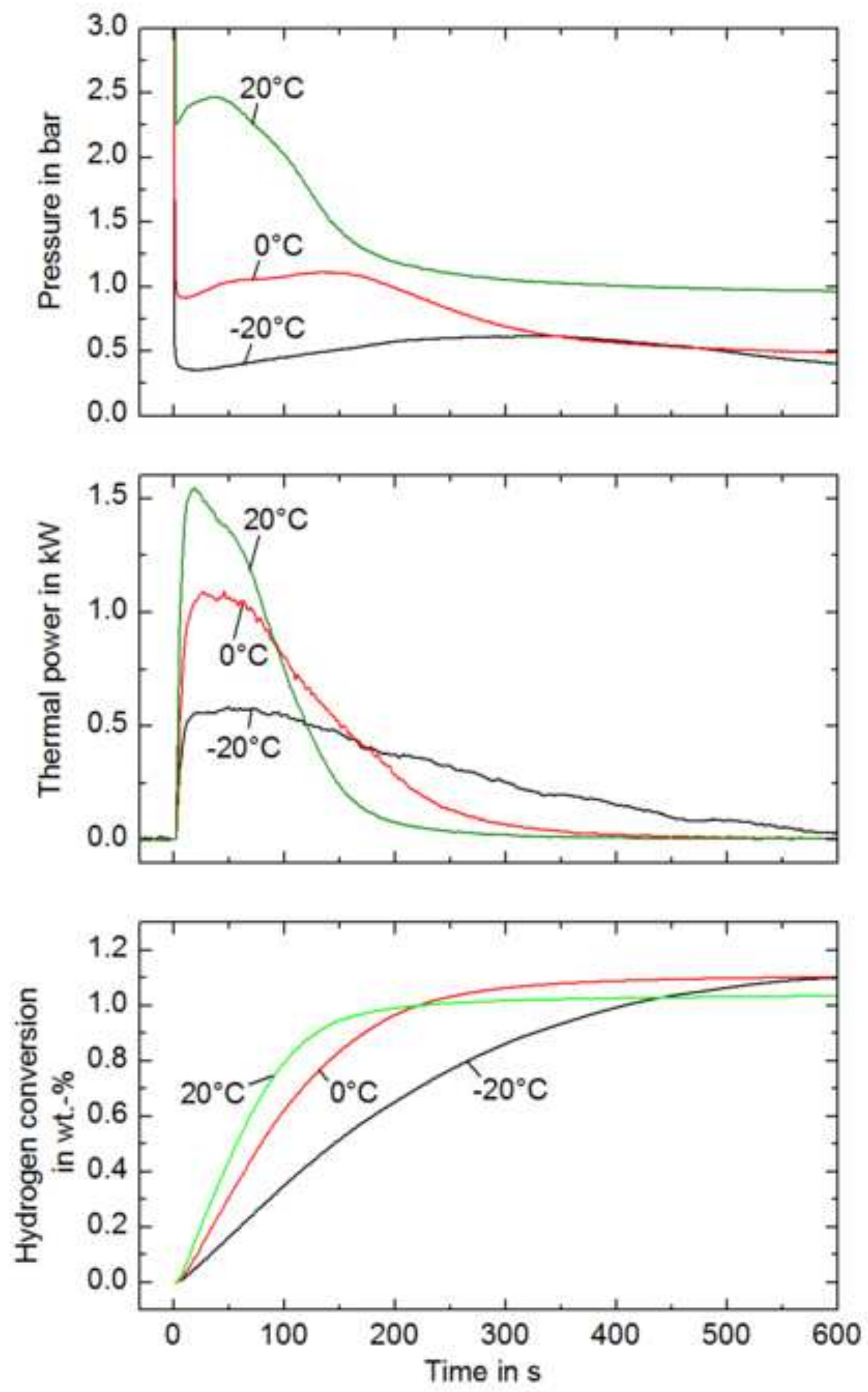

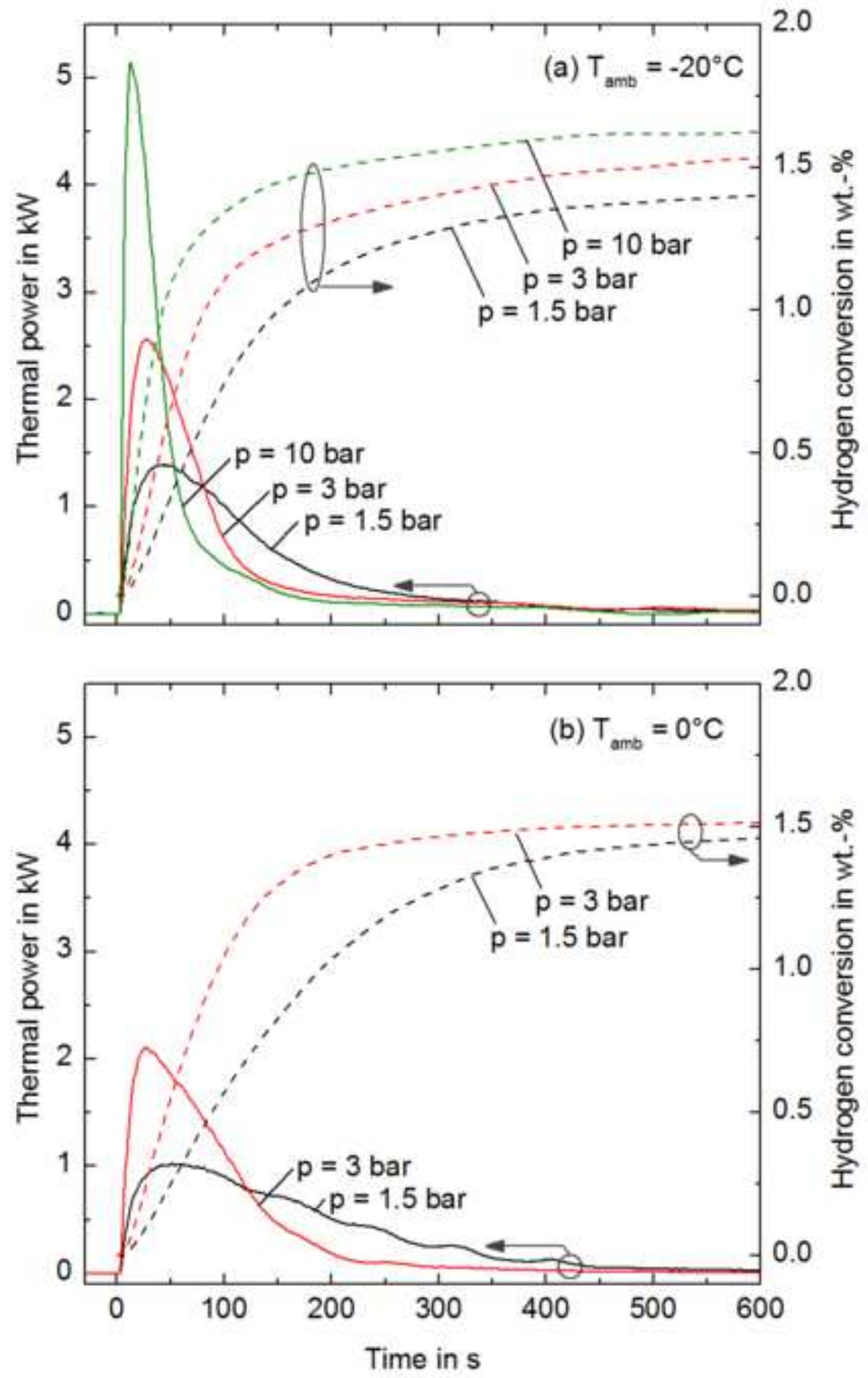
Click here to download high resolution image

3 bar
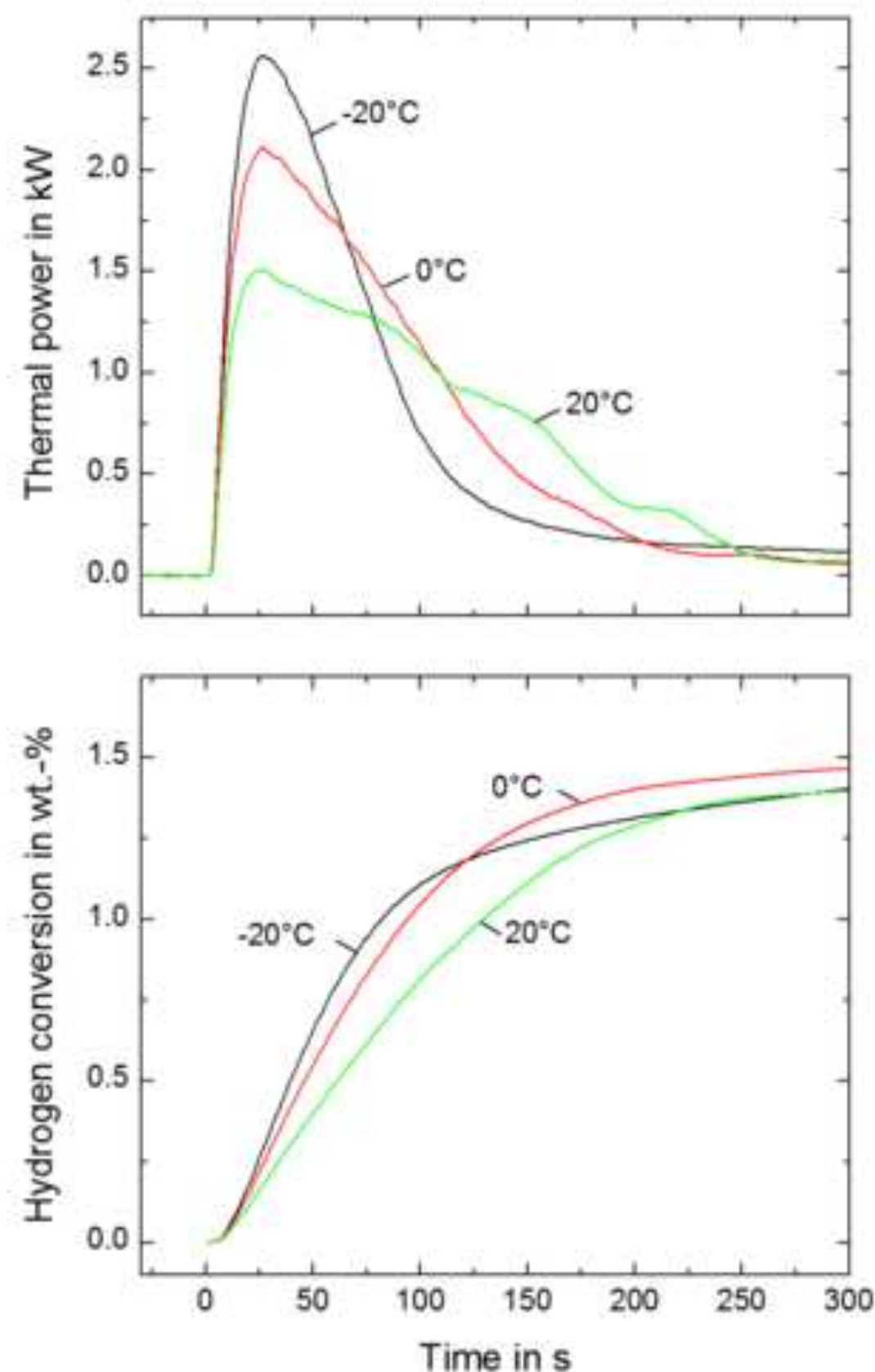

1.5 bar
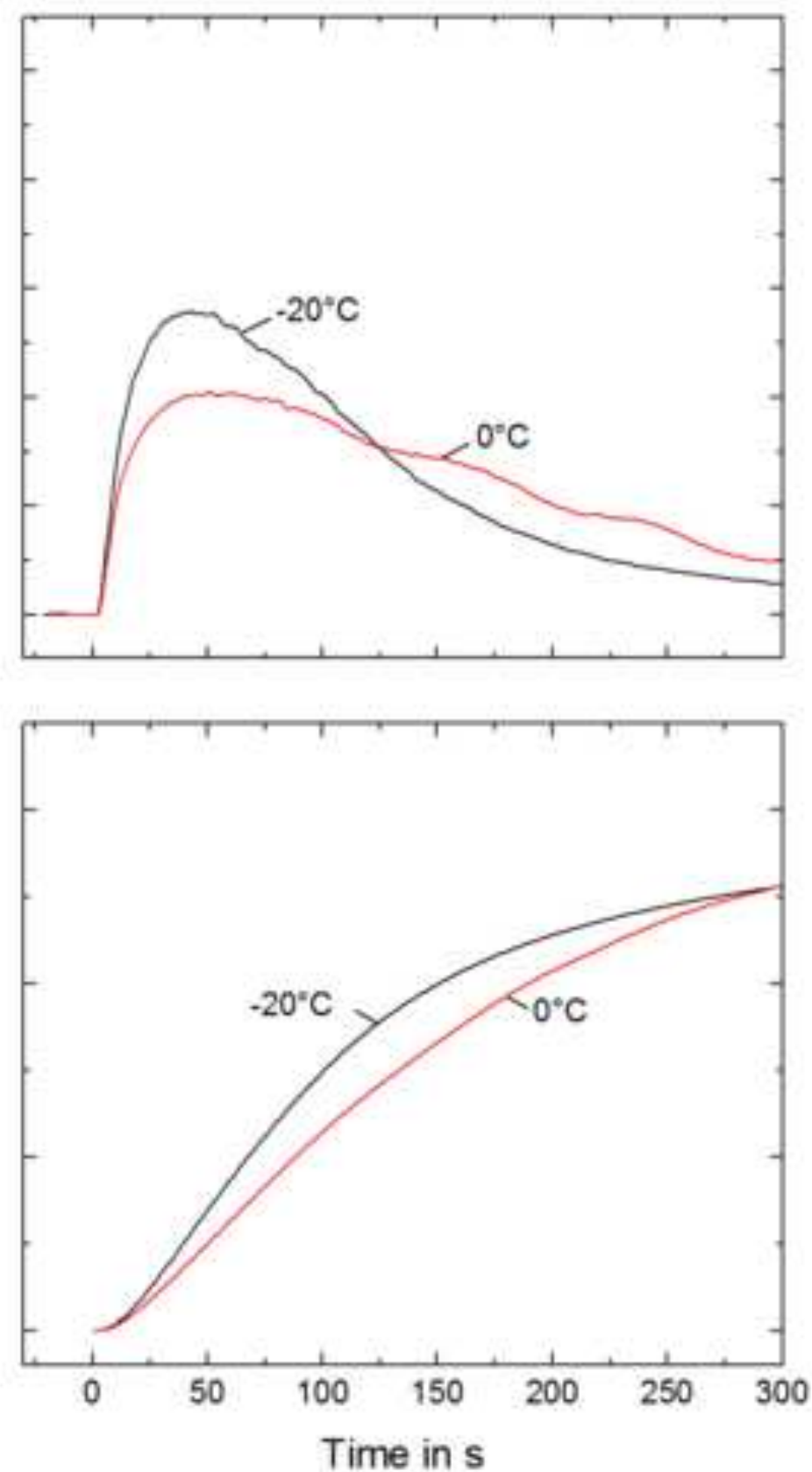

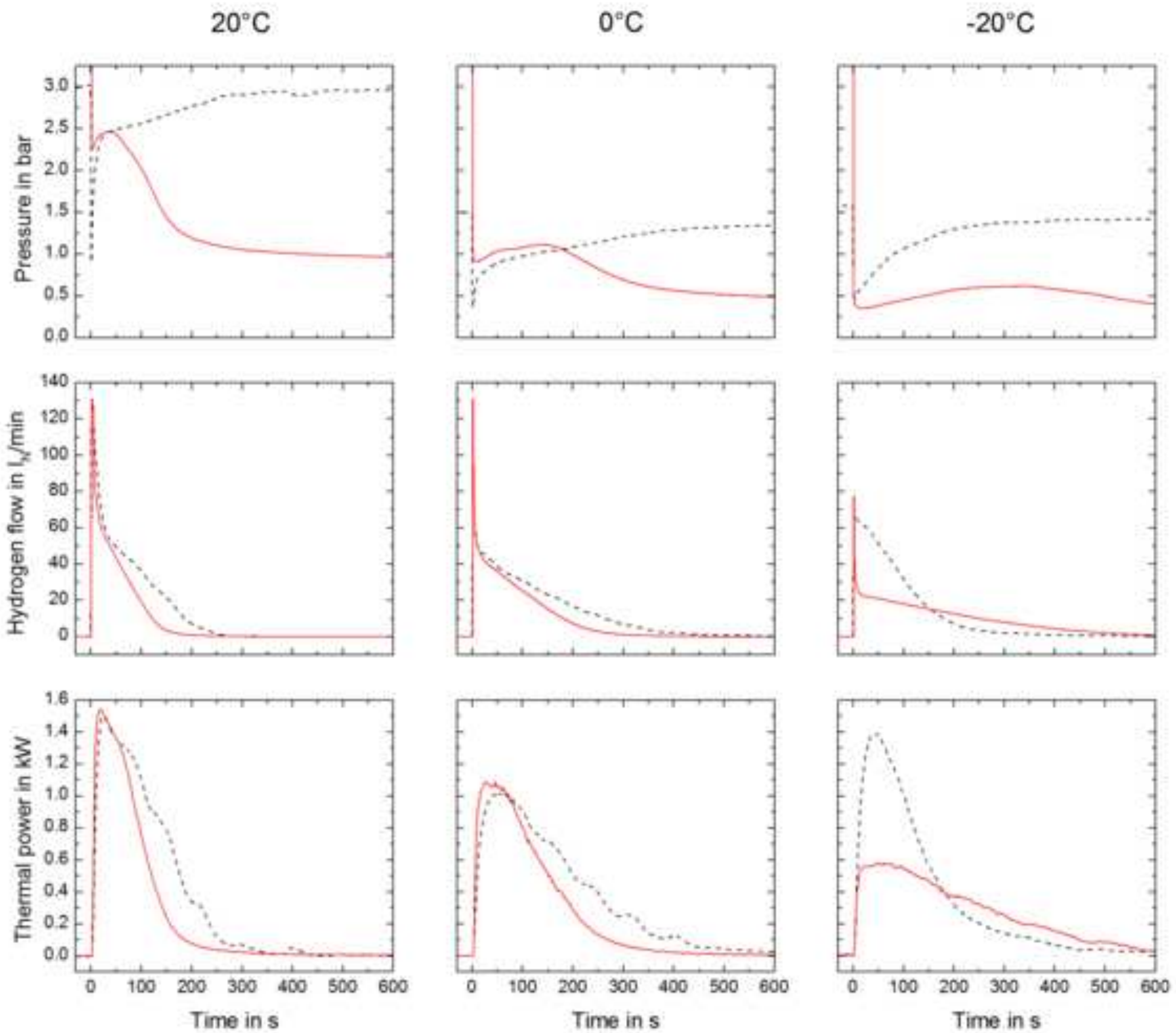